Original Article

\title{
GCMS BASED METABOLIC PROFILING OF ESSENTIAL OIL OF CITRUS MACROPTERA MONTRUZ. LEAVES AND PEEL, ASSESSMENT OF IN VITROANTIOXIDANT AND ANTI- INFLAMMATORY ACTIVITY
}

\author{
KHUMUKCHAM NONGALLEIMA1, 2 , T. AJUNGLA1, CHINGAKHAM BRAJAKISHORE SINGH*2 \\ ${ }^{1}$ Department of Botany, Nagaland University, Lumami-798627, Nagaland, India. ${ }^{2}$ Institute of Bioresources and Sustainable Development \\ (IBSD), Takyelpat, Imphal-795001, Manipur, India \\ Email: kishore.ibsd@nic.in \\ Received: 02 May 2017 Revised and Accepted: 13 Jul 2017
}

\section{ABSTRACT}

Objective: The present investigation was designed for Gas Chromatography Mass Spectrometry (GCMS) based metabolite profiling of Citrus macroptera Montruz. Leaves and peel oils followed by assessment of in vitro antioxidant and anti-inflammatory activity.

Methods: Essential oil was extracted from leaves and peels of Citrus macroptera Montruz. The oil samples were subjected to GCMS analysis using Shimadzu GCMS-QP 2010 equiped with an AOC-2oi auto-injector and AOC-2os autosampler units. In vitro antioxidant activities were evaluated using DPPH radical scavenging, reducing power and nitric oxide reducing method. In vitro anti-inflammatory activity was evaluated using protease inhibitory assay, heat induced haemolysis and albumin denaturation assay.

Results: Both the peels and leaves of Citrus macroptera Montruz. Yielded good amount of essential oil. 57 compounds each were identified from leaves as well as peel of $C$. macroptera. 10 common compounds have been detected in both the oil samples. Peels oil showed $\mathrm{IC}_{50}$ at $118.07 \mu \mathrm{g} / \mathrm{ml}$ and that of leaves showed $\mathrm{IC}_{50}$ at $252.93 \mu \mathrm{g} / \mathrm{ml}$ in DPPH $(1,1$-diphenyl-2-picrylhydrazyl) assay. In reducing assay, peel and leaves oil showed IC 50 at $122.5 \mu \mathrm{g} / \mathrm{ml}$ and $208.24 \mu \mathrm{g} / \mathrm{ml}$. In albumin denaturation, the peels showed $\mathrm{IC}_{50}$ at $73.91 \mu \mathrm{g} / \mathrm{ml}$ and that of leaves showed IC 50 at $87.48 \mu \mathrm{g} / \mathrm{ml}$.

Conclusion: The oil yield denotes peel as better source of volatile oil than leaves. Essential oil of peel showed more anti-oxidant and antiinflammatory activity than that of leaves essential oil.

Keywords: GCMS, Citrus macroptera Montruz., Essential oil, Antioxidant activity and anti-inflammatory activity

(C) 2017 The Authors. Published by Innovare Academic Sciences Pvt Ltd. This is an open access article under the CC BY license (http://creativecommons.org/licenses/by/4.0/] DOI: http://dx.doi.org/10.22159/ijpps.2017v9i9.19593

\section{INTRODUCTION}

Oxidative stress is a state of physiological condition, induced by overabundance of oxidants, including reactive oxygen species such as free radicals, oxygen ions and peroxide. Oxidative damage by free radicals is associated with many diseases; cancer and heart diseases is the most common [1-3]. The amount of the antioxidants generated in the body might be inadequate, particularly under conditions of oxidative stress or inflammation when free radicals production increases [4]. Thus, adequate amount of antioxidants is required to prevent building up of free radicals and oxidative damage in our body [5]. Inflammation is a biological response to noxious stimuli such as pathogens that cause tissue and cell damage [6]. It is classified as either acute or chronic, depending on whether it involves a short response or a prolonged one, respectively [7]. Citrus macroptera Montr. is a semi-wild species of the Rutaceae family and the Citrus genus [8]. The fruit (i.e., the peel) is used as an ingredient in different types of meat and chicken dishes, as well as in the preparation of pickles [9]. Traditionally, the fruit has been used to treat several diseases, such as hypertension, stomach pain and alimentary disorders [10-11]. It should be noted that Melanesian papeda, as well as other variations in several languages (e. g., English, Italian, French, Spanish, Chinese, and Japanese) may apply to varieties of $C$. macroptera.

Moreover, C. macroptera is now considered to be identical to other species (e. g., Citrus combara Raf. and C. kerrii (Swingle) Tanaka from Vietnam and Thailand) [12]. Safford, 1905 [13] gave a firsthand account describing the use of the fruit pulp of this species in Guam, not only for washing the hair, but also as a substitute for soap to wash clothes. This species is also used in complex remedies against various diseases (Yuanga region) including epilepsy-like symptoms (Nelemwa) [14].
Essential oils are natural volatile compounds that exhibit strong odors and are produced as secondary metabolites by aromatic plants [15]. They comprise complex mixtures of substances present in quite different concentrations, such as terpene and phenylpropanoid constituents. Historically, they have been used for various medicinal purposes, ranging from skin problems to cancer treatment and are known for their antimicrobial, anti-inflammatory, sedative and analgesic properties [16].

Citrus by-products release from processing plants represent rich source of naturally occurring flavonoids [17]. The peel contains the highest amount of flavonoids than in other parts [18] and those flavonoids represent in citrus fruits belong to six peculiar classes according to their structure. They are: flavones; flavanones; flavonols; isoflavones; anthocyanidins and flavanols [19].

In the past decades, the therapeutic potential of essential oils and their constituents has been the target of researchers in the pursuit of novel drugs of plant origin, particularly those exhibiting antiinflammatory action, to be used in the prevention or treatment of diseases [20].

Thus, the present study was done to assess the volatile compounds in the essential oil of peel and leaves of Citrus macroptera Montruz.

\section{MATERIALS AND METHODS}

\section{Collection}

Fresh leaves and fruits of Citrus macroptera Montruz. Was collected from Kwatha village, Chandel district of Manipur. It was identified by scientists of IBSD, Imphal and faculty of Botany Department, Nagaland University (fig. 1A). A voucher specimen was deposited at IBSD with voucher number IBSD/M-1031A. 


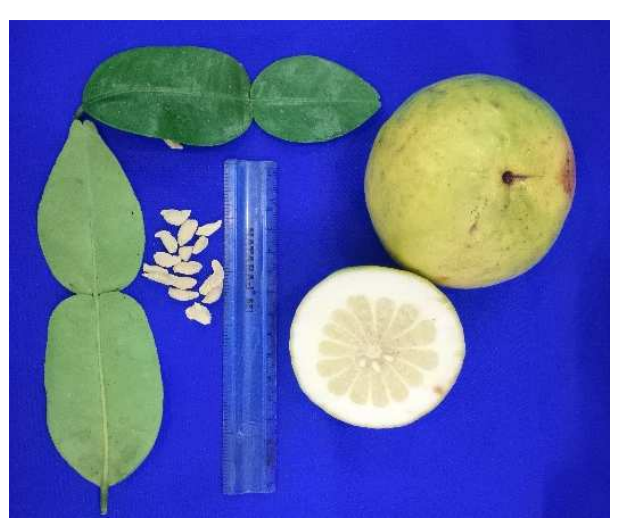

Fig. 1: Leaves, fruits and seeds of Citrus macroptera Montruz

\section{Extraction}

The peel of the collected fresh fruit was freshly grated using a fine grater. Flavedo the coloured portion of the peel was taken. Leaves were washed to remove dust and dirt. $560 \mathrm{~g}$ of the finely grated peel and $1 \mathrm{~kg}$ leaves were separately extracted by hydro distillation with the help of Clevenger type apparatus for 3-4 h.

The collected oil droplets along with water was transferred to a conical flask and dried over anhydrous sodium sulfate (approx. 1g). The resulting solution was filtered through a funnel containing a cotton plug to enable complete removal of sodium sulfate. The essential oil yield were measured. The extracted oils were stored at $4{ }^{\circ} \mathrm{C}$ until gas chromatographic determination of its components and bioactivity assays were done.

\section{Chemicals used}

1, 1-Diphenyl-2-picryl hydrazil (DPPH), L-ascorbic acid, Trypsin were purchased from HiMedia, Bengaluru. Disodium hydrogen phosphate, sodium dihydrogen phosphate for preparing sodium phosphate buffer were purchased from Merck Millipore, Germany. Dimethylsulfoxide, Potassium ferricyanide, Griess reagent, Sodium nitroprusside, Casein, Tichloroacetic acid, diclofenac sodium, bovine serum albumin were purchased from Sigma Aldrich, USA.

\section{Gas chromatographic analysis of essential oil extract}

Gas chromatographic mass spectrometry analysis was carried out at Advanced Instrumentation Research Facility (AIRF), JNU, New Delhi on a Shimadzu GCMS-QP 2010 equiped with an AOC-2oi auto-injector and AOC-2os autosampler units, column Rtx-5 MS (Restek Corporation). The column length was $30 \mathrm{~m}, 0.25 \mathrm{~mm}$ diameter and $0.25 \mu \mathrm{m}$ film thickness). Column temperature was initially kept at 50 ${ }^{\circ} \mathrm{C}$, then gradually increased to $280^{\circ} \mathrm{C}$ at $5{ }^{\circ} \mathrm{C} / \mathrm{min}$ rate, column pressure was $69.0 \mathrm{KPa}$. Detector interface temperature was $270^{\circ} \mathrm{C}$, Carrier gas was helium. Purge flow was $3.0 \mathrm{ml} / \mathrm{min}$. Injection temperature was $260^{\circ} \mathrm{C} .1$ microlitre of sample was injected in split mode in a 1:10 split ratio by auto sampler attached to the instrument. Flow rate was $1.21 \mathrm{ml} / \mathrm{min}$.

In mass spectrophotometry, ion source temperature was $230{ }^{\circ} \mathrm{C}$, interface temperature was kept at $270{ }^{\circ} \mathrm{C}$, solvent cut time at 2.50 min. threshold at 1000 . Temperature program used was $2 \mathrm{~min}$. hold at $50{ }^{\circ} \mathrm{C}$ followed by $3{ }^{\circ} \mathrm{C} / \mathrm{min}$ ramp to reach temperature of $210{ }^{\circ} \mathrm{C}$ held for $0 \mathrm{~min}$., and final ramp of $8{ }^{\circ} \mathrm{C} / \mathrm{min}$. to reach the final temperature of $280^{\circ} \mathrm{C}$ held for $8 \mathrm{~min}$. The total length of run was $72.07 \mathrm{~min}$. with scan range of $40-650 \mathrm{~m} / \mathrm{z}$ and scan speed 333 $\mathrm{amu} / \mathrm{sec}$.

\section{Data acquisition and processing}

Chromatograms and mass spectra recorded were acquired by GCMS 2010QP-PLUS (Shimadzu) and processed by GCMS Solution post run analysis software (ver. 2.5) provided with the instrument. The components were identified based on the comparison of their retention indices relative to $n$-alkanes series and mass spectra with those of authentic samples using commercially available mass spectral libraries NIST 05, NIST 08 with a similarity index (SI) higher than $75 \%$.

\section{Antioxidant activity \\ DPPH radical scavenging assay}

The free radical scavenging activity of the essential oil were measured by DPPH method. $0.1 \mathrm{mmol}$ solution of DPPH in ethanol was prepared. Then, $1 \mathrm{ml}$ of this solution was added to $3 \mathrm{ml}$ ofessential oil (prepared 1:1 in DMSO) and L-Ascorbic acid (positive control) solution at different doses $(10-100 \mu \mathrm{g} / \mathrm{ml})$. The mixture were shaken vigorously and allowed to stand at room temperature for $30 \mathrm{~min}$. Then the absorbance was measured at $517 \mathrm{~nm}$ in Thermo Multiscan Spectrum (Thermo Scientific). Lower absorbance of the reaction mixture indicated higher free radical scavenging activity [20].

Percentage DPPH free radical inhibition was calculated and this activity was expressed as an inhibition concentration 50 (IC $\left.{ }_{50}\right)$. The percentage inhibition was calculated by using the formula.

$$
\% \text { Inhibition }=\frac{\text { Control OD }- \text { Test OD Control }}{\text { Control OD }} \times 100
$$

\section{Reducing power assay}

The reducing power was determined according to the method of Das et al., 2014[21] with little modification.100 $\mu \mathrm{l}$ of essential oil (prepared 1:1 in DMSO) with different concentrations (10$100 \mu \mathrm{g} / \mathrm{ml}$ ) were mixed with $100 \mu \mathrm{l}$ of $0.2 \mathrm{M}$ sodium phosphate buffer (pH 6.6) and $100 \mu \mathrm{l}$ of $1 \%$ Potassium fericyanide. The reaction mixture was incubated at $50{ }^{\circ} \mathrm{C}$ for 20 minute. After incubation, $100 \mu \mathrm{l}$ of $10 \%$ trichloro acetic acid (w/v) were added. It was then centrifuged at $5000 \mathrm{rpm}$ for $10 \mathrm{~min}$ (Eppendorf centrifuge $5430 \mathrm{R})$. The upper layer $(200 \mu \mathrm{l})$ was mixed with $200 \mu \mathrm{l}$ deionized water and $40 \mu \mathrm{l}$ of $0.1 \%$ ferric chloride. The absorbance was read at $700 \mathrm{~nm}$ in a 96 well microplate reader (Thermo Scientific). Higher absorbance indicates higher reducing power. The assays were carried out in triplicate and the results are expressed as mean values \pm standard error mean. Ascorbic acid was used as standard. Percentage inhibition was calculated and the activity was expressed as an inhibition concentration 50 ( $\left.\mathrm{IC}_{50}\right)$.

The percent increase in reducing power was calculated using the following equation.

$$
\% \text { reduction }=[1-(1-\mathrm{As} / \mathrm{Ac})] \times 100
$$

As-maximum absorbance of max concentration of standard,

\section{Ac-absorbance of sample}

\section{Nitric oxide reducing assay}

Nitric oxide reducing assay was done following Gangwar et al. 2014[22] with minor modification. Under aerobic conditions, nitric oxide reacts with oxygen to produce stable products (nitrates and nitrite). The quantities of which can be determined using Griess reagent. $500 \mu \mathrm{l}$ of test sample with different concentration (10-100 $\mu \mathrm{g} / \mathrm{ml}$ ) was mixed with $2 \mathrm{ml}$ of $10 \mathrm{mmol} \mathrm{SNP}, 500 \mu \mathrm{l}$ of $50 \mathrm{mmol}$ phosphate buffer saline $\mathrm{pH}$ 7.4. They were incubated at $25{ }^{\circ} \mathrm{C}$ for $150 \mathrm{~min}$. Griess reagent $(500 \mu \mathrm{l})$ was added and incubated at $25^{\circ} \mathrm{C}$ for 30 minute. The absorbance was read at $540 \mathrm{~nm}$. A phosphate buffer saline served as blank.

\section{In vitro anti-inflammatory activity}

\section{Protease inhibitory assay}

$1 \mathrm{ml}$ of trypsin $\left(0.5 \mathrm{mg}\right.$. $\left.\mathrm{ml}^{-1}\right)$ prepared in $0.1 \mathrm{M}$ phosphate buffer, $\mathrm{pH}-7$ was pre-incubated with $1 \mathrm{ml}$ of sample with different concentration $(10-100 \mathrm{ug} / \mathrm{ml})$ at $37^{\circ} \mathrm{C}$ for 15 minute. After incubation $2 \mathrm{ml}$ of $1 \%$ casein prepared in $0.1 \mathrm{M}$ phosphate was added. It was then incubated at $37^{\circ} \mathrm{C}$ for 30 minute. The reaction was terminated by adding $2.5 \mathrm{ml}$ of $0.44 \mathrm{M}$ Trichloroacetic acid. It was transferred to centrifuge tube and centrifuge at $10,000 \mathrm{rpm}$ for 15 minute. Supernatant was taken and OD was measured at $280 \mathrm{~nm}$ [23]. 


\section{Heat induced haemolysis assay}

$2 \mathrm{ml}$ of reaction mixture consisting of $1 \mathrm{ml}$ of test sample solution and $1 \mathrm{ml}$ of $10 \% \mathrm{RBC}$ suspension was taken in $2 \mathrm{ml}$ micro centrifuge tube. It was incubated at $56{ }^{\circ} \mathrm{C}$ for $30 \mathrm{~min}$. in water bath. The reaction mixture was cooled and centrifuged at $2500 \mathrm{rpm}$ for $5 \mathrm{~min}$. The supernatant was taken and absorbance was taken at $560 \mathrm{~nm}$. Saline and Diclofenac sodium was taken as control and standard reference respectively [24].

\section{Albumin denaturation assay}

The in vitro anti-inflammatory activity was assessed using inhibition of albumin denaturation method. Reaction mixture of $1 \%$ aqueous solution of bovine serum albumin (Sigma) and an essential oil at different concentration $(10-100 \mu \mathrm{g} / \mathrm{ml})$ was taken in a centrifuge tube and $\mathrm{pH}$ was adjusted to $6.8 \mathrm{using} 1 \mathrm{~N} \mathrm{HCl}$. It was incubated at 37 ${ }^{\circ} \mathrm{C}$ for $20 \mathrm{~min}$ followed by heating at $57^{\circ} \mathrm{C}$ for $20 \mathrm{~min}$. The solution was cooled and absorbance was read at $660 \mathrm{~nm}$ [25].

\section{Statistical analysis}

The results were expressed as the mean $\pm \operatorname{SEM}(n=3)$. Linear regression was used to calculate IC50. Results were considered significant at ${ }^{* * *} \mathrm{P}<0.001$, or ${ }^{* *} \mathrm{P}<0.01$ or ${ }^{*} \mathrm{P}<0.05$ when compared test groups $\mathrm{v} / \mathrm{s}$ control group. For numerical results, one-way analysis of variance (ANOVA) with Tukey-Kramer Multiple Comparisons post tests were performed using GraphPad InStat Version 3 (GraphPad Software). All the graphs and fig. were drawn using GraphPad Prism.

\section{RESULTS AND DISCUSSION}

Hydrodistillation of peel and leaves of $C$. macroptera yielded $8 \mathrm{ml}$ for peel and $4.54 \mathrm{ml}$ for leaves which represent $1.43 \%$ and $0.46 \%$ respectively. Hydrodistillation of the leaves of $C$. macroptera yielded $1.67 \%$ of essential oil, GC/MS Analysis of the C. macroptera essential oil allowed the identification of 35 compounds accounting for $99.1 \%$ of the total composition [25]. 57 compounds each were identified from leaves and peel of C. macroptera. Identified compounds in leaves are presented accounting to $96.79 \%$ of total composition negating the trace amount $(<0.1 \%)$, and that of peels accounting to 99.18\% of total composition. Relative percentage composition of essential oil of the leaves (table 1) and peel (table 2) are presented.

In both the essential oil, 10 same compounds have been detected (table 3). However, the percentage oils components calculated as the percent peak area were different. Chromatogram of leaves and peel essential oil were presented in fig.1 and fig.2. The major volatile component present in peels were Bicyclo [4.1.0] heptane, 7-(1methylethylidene)-(60.03\%), Mentha-2, 8-dien-1-ol<trans-,para$>(4.0 \%)$, Limonene oxide (3.53\%), trans Carveol (2.67\%) whereas in leaves essential oilmajor components were 2-methylaminobenzoic acid methyl ester (57.16 \%), bicyclo [4.1.0] heptane, 7-(1methylethylidene)-(23.23\%), $\beta$-pinene (8.79 \%), ocimene<(E)BETA->DB5-519 (3.29\%). Citrus macroptera has been reported to contain lupeol, stigmasterol, beta-pinene, limonene, betacaryophyllene, geranial edulinine, ribalinine and isoplatydesmine [26-28].

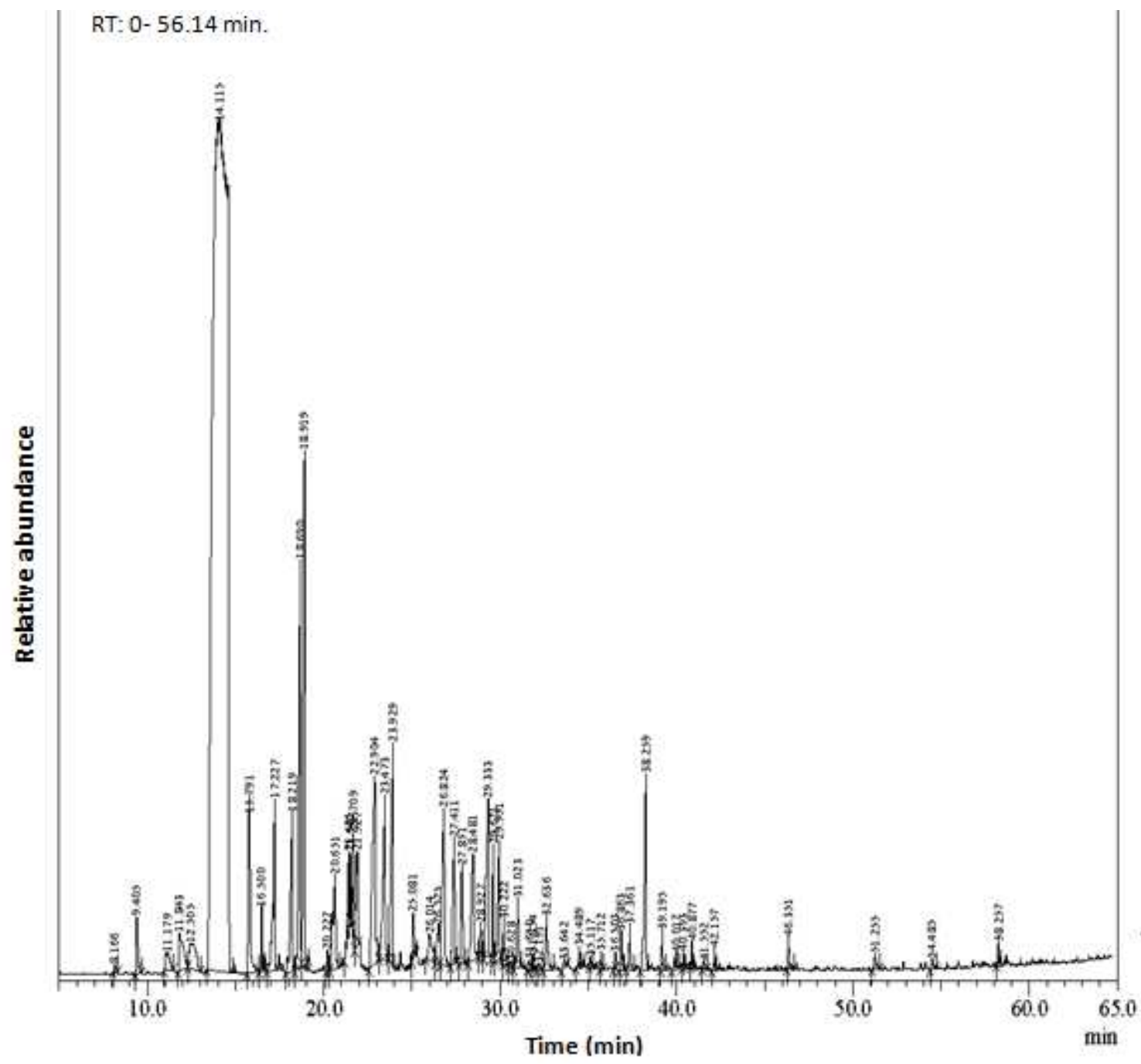

TIC* 1.00

Fig. 1: Chromatogram of leaves essential of Citrus macroptera Montruz., RT-retention time 
Table 1: Relative percentage chemical composition of essential oil of leaves of citrus macroptera montruz

\begin{tabular}{|c|c|c|c|}
\hline Peak & Compound & R. time & Area \% \\
\hline 1 & Nonane $<\mathrm{n}->$ & 8.062 & $\operatorname{tr}$ \\
\hline 2 & Thujene<alpha-> & 9.141 & $\operatorname{tr}$ \\
\hline 3 & BICYCLO[3.1.1]HEPT-2-ENE, 2,6,6-TRIMETHYL- & 9.429 & $\operatorname{tr}$ \\
\hline 4 & BICYCLO[2.2.1]HEPTANE, 2,2-DIMETHYL-3-METHYL & 10.013 & $\operatorname{tr}$ \\
\hline 5 & BICYCLO[3.1.1]HEPTANE, 6,6-DIMETHYL-2-METHYL & 11.420 & 8.79 \\
\hline 6 & 1,6-OCTADIENE, 7-METHYL-3-METHYLENE- & 11.895 & $\operatorname{tr}$ \\
\hline 7 & OCTANAL & 12.423 & $\operatorname{tr}$ \\
\hline 8 & Bicyclo[4.1.0]heptane, 7-(1-methylethylidene)- & 14.022 & 23.23 \\
\hline 9 & 1,3,7-OCTATRIENE, 3,7-DIMETHYL-, (E)- & 14.149 & 0.17 \\
\hline 10 & OCIMENE $<($ E) - BETA->DB5-519 & 14.675 & 3.29 \\
\hline 11 & 1,4-CYCLOHEXADIENE, 1-METHYL-4-(1-METHYLET & 15.040 & 0.28 \\
\hline 12 & BENZENAMINE, N-METHYL- & 15.348 & 0.36 \\
\hline 13 & 2-FURANMETHANOL, 5-ETHENYLTETRAHYDRO-. AL & 15.666 & $\operatorname{tr}$ \\
\hline 14 & 2,7,7-TRIMETHYL-3-OXATRICYCLO[4.1.1.0 2,4 ]OCT & 15.880 & $\operatorname{tr}$ \\
\hline 15 & CYCLOHEXENE, 1-METHYL-4-(1-METHYLETHYLIDE & 16.339 & $\operatorname{tr}$ \\
\hline 16 & 1,6-OCTADIEN-3-OL, 3,7-DIMETHYL- & 16.987 & 0.76 \\
\hline 17 & NONANAL & 17.109 & $\operatorname{tr}$ \\
\hline 18 & 1H-PYRAZOLE, 3-METHYL- & 17.531 & $\operatorname{tr}$ \\
\hline 19 & Mentha-2,8-dien-1-ol<trans-, p-> & 17.897 & $\operatorname{tr}$ \\
\hline 20 & Limonene oxide<cis-> & 18.468 & $\operatorname{tr}$ \\
\hline 21 & P-MENTHA-E-2,8(9)-DIEN-1-OL & 18.575 & $\operatorname{tr}$ \\
\hline 22 & (Z)-2,2-Dimethyl-3-(3-methylpenta-2,4-dien-1-yl)oxirane & 18.892 & $\operatorname{tr}$ \\
\hline 23 & Pinocarvone & 19.848 & $\operatorname{tr}$ \\
\hline 24 & 1-ISOPROPYL-4-METHYL-3-CYCLOHEXEN-1-OL & 20.612 & 0.56 \\
\hline 25 & Heptanedinitrile, 4-acetyl-4-methyl- & 20.990 & $\operatorname{tr}$ \\
\hline 26 & (+)-ALPHA-TERPINEOL (P-MENTH-1-EN-8-OL) & 21.257 & $\operatorname{tr}$ \\
\hline 27 & 2,4,6-Trimethyl-1,3,6-heptatriene & 21.442 & $\operatorname{tr}$ \\
\hline 28 & DECANAL & 21.853 & $\operatorname{tr}$ \\
\hline 29 & 2,6-Dimethyl-3,5,7-octatriene-2-ol,E,E- & 22.034 & $\operatorname{tr}$ \\
\hline 30 & Carveol<trans-> & 22.546 & $\operatorname{tr}$ \\
\hline 31 & 2-CYCLOHEXEN-1-OL, 2-METHYL-5-(1-METHYLETHE & 23.078 & $\operatorname{tr}$ \\
\hline 32 & 2-CYCLOHEXEN-1-ONE, 2-METHYL-5-(1-METHYLET & 23.659 & $\operatorname{tr}$ \\
\hline 33 & Dihydro carveol<neoiso-> & 25.061 & $\operatorname{tr}$ \\
\hline 34 & Formamide, N-methyl-N-phenyl- & 25.486 & 0.11 \\
\hline 35 & 2H-PYRAN-2-CARBOXALDEHYDE, 3,4-DIHYDRO-2,5- & 27.630 & $\operatorname{tr}$ \\
\hline 36 & Copaene<alpha-> & 29.543 & $\operatorname{tr}$ \\
\hline 37 & Elemene<beta-> & 30.251 & $\operatorname{tr}$ \\
\hline 38 & 2-METHYLAMINOBENZOIC ACID METHYL ESTER & 32.222 & 57.16 \\
\hline 39 & 1,4,8-CYCLOUNDECATRIENE, 2,6,6,9-TETRAMETHYL & 33.323 & $\operatorname{tr}$ \\
\hline 40 & Anthranilate<methyl-, N,N-dimethyl-> & 34.237 & $\operatorname{tr}$ \\
\hline 41 & Bicyclogermacrene & 34.881 & 0.12 \\
\hline 42 & Farnesene<(E,E)-, alpha-> & 35.197 & $\operatorname{tr}$ \\
\hline 43 & NAPHTHALENE, 1,2,3,5,6,8A-HEXAHYDRO-4,7-DIME & 35.849 & $\operatorname{tr}$ \\
\hline \multirow[t]{2}{*}{44} & Methyl anthranilate & 37.212 & 0.17 \\
\hline & 1,6,10-Dodecatrien-3-ol, 3,7,11-trimethyl-, (E)- & 37.459 & 0.87 \\
\hline 46 & $(-)$-Spathulenol & 38.097 & 0.39 \\
\hline 47 & 1,1,4,7-TETRAMETHYLDECAHYDRO-1H-CYCLOPROP & 38.289 & 0.18 \\
\hline 48 & Globulol & 38.607 & 0.10 \\
\hline 49 & Cryptomeridiol & 38.973 & $\operatorname{tr}$ \\
\hline 50 & GLOBULOL DB5-1841 & 39.822 & $\operatorname{tr}$ \\
\hline 51 & T-Muurolol & 40.415 & $\operatorname{tr}$ \\
\hline 52 & . alpha.-Cadinol & 40.905 & 0.10 \\
\hline 53 & Farnesol< $<(2 Z, 6 Z)->$ & 43.329 & $\operatorname{tr}$ \\
\hline 54 & Cycloheptane, 4-methylene-1-methyl-2-(2-methyl-1-propen- & 44.679 & $\operatorname{tr}$ \\
\hline 55 & HEXADECANOIC ACID & 51.407 & $\operatorname{tr}$ \\
\hline 56 & Benzoic acid, 2-(2-methoxycarbonylphenylaminomethylami & 53.282 & $\operatorname{tr}$ \\
\hline \multirow[t]{2}{*}{57} & 2-HEXADECEN-1-OL, 3,7,11,15-TETRAMETHYL-, [R-[R & 56.143 & 0.15 \\
\hline & & & 96.79 \\
\hline
\end{tabular}

R. Time-retention time, tr-trace $(<0.1 \%)$

The antioxidant activity of essential oil extracted from leaves and peel of Citrus macroptera were investigated. Peels oil showed $\mathrm{IC}_{50}$ at $118.07 \mu \mathrm{g} / \mathrm{ml}$ and that of leaves showed $\mathrm{IC}_{50}$ at $252.93 \mu \mathrm{g} / \mathrm{ml}$ in DPPH (1, 1-diphenyl-2-picrylhydrazyl) assay (table 4). In reducing assay, peel and leaves oil showed $\mathrm{IC}_{50}$ at $122.5 \mu \mathrm{g} / \mathrm{ml}$ and 208.24 $\mu \mathrm{g} / \mathrm{ml}$ (table 4 ). In nitric oxide assay essential oil of peel and leaves showed 236.71 and 135.43 as their respective IC $_{50 \text { s. }}$ Thus, the peels proved to be more potential candidate of antioxidant as compared to leaves essential oil. We are reporting the antioxidant potential of the essential oil of Citrus macroptera Montruz. Although there was a report that the oil did not exhibit any in vitro free-radical-scavenging (DPPH) [29]. 


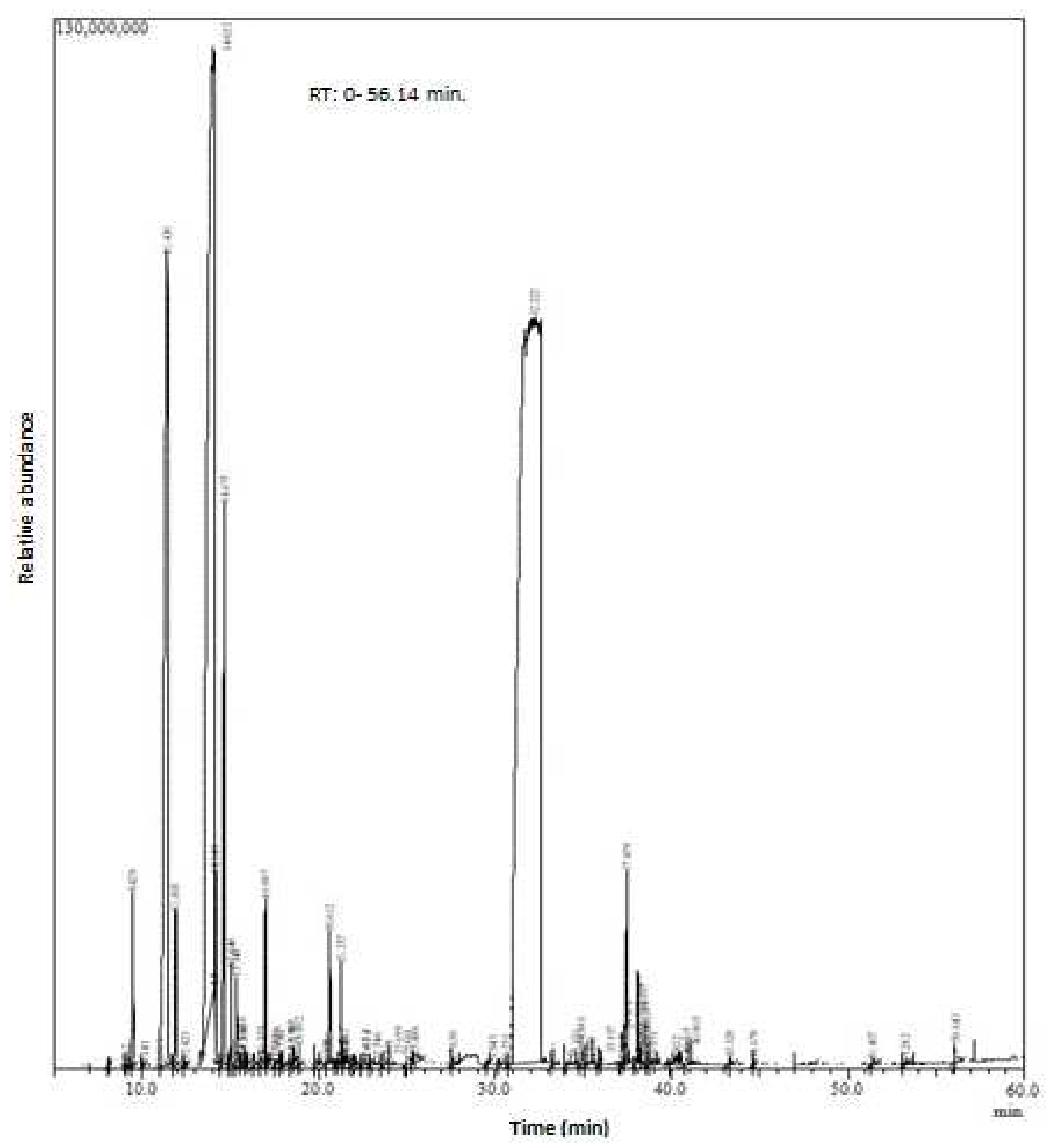

Fig. 2: Chromatogram of peel essential oil Citrus macroptera Montruz, RT-retention time

Table 2: Relative percentage chemical composition of essential oil of peels of Citrus macroptera montruz

\begin{tabular}{|c|c|c|c|}
\hline Peak & Compound & R. Time & Area\% \\
\hline 1 & HEPTANAL & 8.166 & $\operatorname{tr}$ \\
\hline 2 & BICYCLO[3.1.1]HEPT-2-ENE, 2,6,6-TRIMETHYL- & 9.405 & 0.46 \\
\hline 3 & Pinene oxide $<$ beta- $>$ & 11.179 & 0.36 \\
\hline 4 & 1,6-OCTADIENE, 7-METHYL-3-METHYLENE- & 11.843 & 0.75 \\
\hline 5 & OCTANAL & 12.505 & 0.82 \\
\hline 6 & Bicyclo[4.1.0]heptane, 7-(1-methylethylidene)- & 14.115 & 60.03 \\
\hline 7 & 1-OCTANOL & 15.791 & 1.43 \\
\hline 8 & 2-FURANMETHANOL, 5-ETHENYLTETRAHYDRO-. AL & 16.500 & 0.31 \\
\hline 9 & NONANAL & 17.227 & 1.45 \\
\hline 10 & Mentha-2,8-dien-1-ol<trans-, para-> & 18.219 & 1.49 \\
\hline 11 & Limonene oxide $<$ cis- $>$ & 18.690 & 3.53 \\
\hline 12 & Mentha-2,8-dien-1-ol<cis-, para-> & 18.919 & 4.00 \\
\hline 13 & 3-METHYL-3,3A,4,6A-TETRAHYDRO-2(1H)-PENTALE & 20.227 & 0.11 \\
\hline 14 & 2-ISOPROPENYL-5-METHYL-HEX-4-ENAL & 20.651 & 1.26 \\
\hline 15 & 3-CYCLOHEXENE-1-METHANOL,. ALPHA.. ALPHA.,4- & 21.425 & 0.45 \\
\hline 16 & 1,3,6-Heptatriene, 2,5,5-trimethyl- & 21.540 & 0.34 \\
\hline 17 & 1,3,6-Heptatriene, 2,5,6-trimethyl- & 21.709 & 0.45 \\
\hline 18 & DECANAL & 21.927 & 0.92 \\
\hline 19 & Carveol<trans-> & 22.904 & 2.67 \\
\hline 20 & 2-CYCLOHEXEN-1-OL, 2-METHYL-5-(1-METHYLETHE & 23.473 & 1.79 \\
\hline 21 & 2-CYCLOHEXEN-1-ONE, 2-METHYL-5-(1-METHYLET & 23.929 & 2.07 \\
\hline 22 & 2-CYCLOHEXEN-1-ONE, 3-METHYL-6-(1-METHYLET & 25.081 & 0.28 \\
\hline
\end{tabular}




\begin{tabular}{|c|c|c|c|}
\hline 23 & Limonen-10-ol & 26.014 & 0.47 \\
\hline 24 & Undecanal & 26.525 & 0.53 \\
\hline 25 & (3R,6R)-3-Hydroperoxy-3-methyl-6-(prop-1-en-2-yl)cyclohe & 26.824 & 1.71 \\
\hline 26 & (3R,6R)-3-Hydroperoxy-3-methyl-6-(prop-1-en-2-yl)cyclohe & 27.411 & 1.14 \\
\hline 27 & P-MENTHA-1,8-DIEN-4-HYDROPEROXIDE & 27.851 & 0.79 \\
\hline 28 & 1,2-Cyclohexanediol, 1-methyl-4-(1-methylethenyl)- & 28.481 & 1.23 \\
\hline 29 & 3-Heptadecen-5-yne, (Z)- & 28.927 & 0.24 \\
\hline 30 & 2(5H)-Furanone, 4-methyl-3-(2-methyl-2-propenyl)- & 29.333 & 1.71 \\
\hline 31 & Copaene<alpha-> & 29.621 & 0.52 \\
\hline 32 & Sinensal<alpha-> & 29.951 & 1.03 \\
\hline 33 & beta.-copaene & 30.222 & 0.29 \\
\hline 34 & Carvone oxide<cis-> & 30.628 & $\operatorname{tr}$ \\
\hline 35 & Limonene oxide $<$ cis- $>$ & 31.023 & 0.58 \\
\hline 36 & 1-CYCLOHEXENE-1-METHANOL, 4-(1-METHYLETHE & 31.650 & $\operatorname{tr}$ \\
\hline 37 & beta.-copaene & 31.854 & $\operatorname{tr}$ \\
\hline 38 & 2,6,10-DODECATRIEN-1-OL, 3,7,11-TRIMETHYL- & 32.191 & $\operatorname{tr}$ \\
\hline 39 & Limonene oxide $<$ cis- $>$ & 32.636 & 0.52 \\
\hline 40 & Heptan-2-one & 33.642 & $\operatorname{tr}$ \\
\hline 41 & 2,7-Octadiene-1,6-diol, 2,6-dimethyl- & 34.489 & 0.13 \\
\hline 42 & Thujyl acetate & 35.117 & $\operatorname{tr}$ \\
\hline 43 & CADINENE $<$ DELTA- $>$ DB5-1700 & 35.712 & $\operatorname{tr}$ \\
\hline 44 & 1-ISOPROPYL-4,7-DIMETHYL-1,2-DIHYDRONAPHTH & 36.503 & $\operatorname{tr}$ \\
\hline 45 & Hedycaryol & 36.863 & 0.27 \\
\hline 46 & 1,6,10-Dodecatrien-3-ol, 3,7,11-trimethyl-, (E)- & 37.361 & 0.30 \\
\hline 47 & $(-)$-5-OXATRICYCLO $[8.2 .0 .0(4,6)]$ DODECANE,,12-TRIM & 38.259 & 1.63 \\
\hline 48 & (1R,3E,7E,11R)-1,5,5,8-Tetramethyl-12-oxabicyclo[9.1.0]do & 39.195 & 0.22 \\
\hline 49 & Eudesmol<epi-gamma-> & 40.017 & 0.16 \\
\hline 50 & T-Muurolol & 40.393 & $\operatorname{tr}$ \\
\hline 51 & . alpha.-Cadinol & 40.877 & 0.14 \\
\hline 52 & Caryophyllene oxide & 41.552 & $\operatorname{tr}$ \\
\hline 53 & 2-Propenoic acid, tridecyl ester & 42.157 & 0.12 \\
\hline 54 & 2(3H)-NAPHTHALENONE, 4,4A,5,6,7,8-HEXAHYDRO-4 & 46.351 & 0.21 \\
\hline 55 & 3-Methyl-hepta-1,6-dien-3-ol & 51.255 & 0.14 \\
\hline 56 & Isophytol & 54.485 & $\operatorname{tr}$ \\
\hline \multirow[t]{2}{*}{57} & 4,8-DIMETHYLNONA-3,7-DIEN-2-OL & 58.257 & 0.13 \\
\hline & & & 99.18 \\
\hline
\end{tabular}

R. Time-retention time, tr-trace $(<0.1 \%)$

Table 3: Common compound found in essential oil of leaves and rind of Citrus macroptera montruz with their area \%

\begin{tabular}{ll}
\hline Component & $\begin{array}{l}\text { Area \% } \\
\text { leaves essential oil }\end{array}$ \\
\hline BICYCLO[3.1.1]HEPT-2-ENE, 2,6,6-TRIMETHYL- & $\begin{array}{l}\text { Area peels } \\
\text { essential oil }\end{array}$ \\
Bicyclo[4.1.0]heptane, 7-(1-methylethylidene)- & 0.64 \\
NONANAL & 23.23 \\
Limonene oxide<cis-> & $\operatorname{tr}$ \\
P-MENTHA-E-2,8(9)-DIEN-1-OL & $\operatorname{tr}$ \\
Carveol<trans-> & $\operatorname{tr}$ \\
Copaene<alpha-> & $\operatorname{tr}$ \\
1,6,10-Dodecatrien-3-ol, 3,7,11-trimethyl-, (E)- & $\operatorname{tr}$ \\
T-Muurolol & 0.46 \\
alpha.-Cadinol & 0.87 \\
\hline
\end{tabular}

Tr-trace $(<0.1 \%)$

Table 4: In vitro antioxidant activity of essential oil of peels and leaves of Citrus macroptera montruz

\begin{tabular}{lllll}
\hline $\begin{array}{l}\text { Essential oil } \\
\text { of }\end{array}$ & Oil yield \% & $\begin{array}{l}\text { DPPH (IC } 50) \\
\boldsymbol{\mu g} / \mathbf{m l}\end{array}$ & $\begin{array}{l}\text { Reducing power assay } \\
\left(\mathbf{I C}_{\mathbf{5 0}}\right) \boldsymbol{\mu g} / \mathbf{m l}\end{array}$ & $\begin{array}{l}\text { Nitric oxide reducing assay (IC } \\
\boldsymbol{\mu g} \text { ) } / \mathbf{m l}\end{array}$ \\
\hline leaves & & $252.93 \pm 0.004$ & $208.24 \pm 0.08$ & $236.71 \pm 0.01$ \\
Rind & $0.46 \%$ & $118.07 \pm 0.007$ & $122.5 \pm 0.12$ & $135.43 \pm 0.09$ \\
Ascorbic acid & $1.43 \%$ & $5.62 \pm 0.001$ & $8.1 \pm 0.04$ & $7.6 \pm 0.67$ \\
\hline
\end{tabular}

Results are mean \pm SD-standard deviation, $n=3$, DPPH-1, 1-Diphenyl-2-picryl hydrazil

The $\mathrm{IC}_{50}$ of the in vitro anti-inflammatory assay (protease inhibitory, heat induced haemolysis and albumin denaturation) of the essential oil sample are presented in (table 5). In albumin denaturation assay, the peels showed $\mathrm{IC}_{50}$ at $73.91 \mu \mathrm{g} / \mathrm{ml}$ and that of leaves showed $\mathrm{IC}_{50}$ at $87.48 \mu \mathrm{g} / \mathrm{ml}$. The $\mathrm{IC}_{50}$ of the other assay are also presented in the table 5 . The oil yield denotes peel as better source of volatile oil than leaves. Essential oil of peel showed more anti-oxidant and anti-inflammatory activity than leaves oil. Plant essential oils and their components have been known to have biological activities, especially antimicrobial [30], antifungal [31], insecticidal [32], antiparasitic, spasmolytic and antioxidant activities [33]. 
Table 5: In vitro anti-inflammatory activity of peels and leaves of Citrus macroptera montruz

\begin{tabular}{|c|c|c|c|c|}
\hline S. No. & Essential oil sample & $\begin{array}{l}\text { Protease inhibitory assay } \\
\left(\mathrm{IC}_{50}\right) \mu \mathrm{g} / \mathrm{ml} \pm \mathrm{SD}\end{array}$ & $\begin{array}{l}\text { Heat induced haemolysis } \\
\text { (IC } 50) \mu \mathrm{g} / \mathrm{ml} \pm \text { SD }\end{array}$ & $\begin{array}{l}\text { Albumin denaturation assay } \\
\left(\mathrm{IC}_{50}\right) \mu \mathrm{g} / \mathrm{ml} \pm \mathrm{SD}\end{array}$ \\
\hline 1 & C. macroptera leaves & $106.71 \pm 0.11$ & $187 \pm 0.33$ & $87.48 \pm 0.32$ \\
\hline 2 & C. macroptera rind & $96.4 \pm 0.25$ & $124.89 \pm 0.07$ & 73. $91 \pm 0.05$ \\
\hline 3. & Diclofenac sodium & - & $11.79 \pm 0.01$ & $55.8 \pm 0.16$ \\
\hline 4. & Protease inhibitor cocktail (Sigma) & $11.49 \pm 0.008$ & - & - \\
\hline
\end{tabular}

IC-Inhibition Concentration, SD-standard deviation, no. of replicate, $n=3$

In many inflammatory disorders there is excessive activation of phagocytes, production of $\mathrm{O}_{2}$. $\mathrm{OH}$ radicals as well as non-free radicals species $\left(\mathrm{H}_{2} \mathrm{O}_{2}\right)$, which can harm severely tissues either by powerful direct oxidizing action by activating matrix metello protinase damage seen in various arthritic tissues [34, 35]. Due to its implication in virtually all human and animal diseases, inflammation has become the focus of global scientific research, more so, since the currently used anti-inflammatory agents both steroidal and nonsteroidal are prone to evoking serious adverse reactions [36, 37]. Recently fruits and vegetables have played a significant part in the chemoprevention of diseases and aging are recognized as natural antioxidants; antioxidant compounds play a crucial role in the treatment of various diseases related to degenerative disorders namely cardiovascular and brain diseases, arthritis, diabetes, cancer, immune system decline by acting as free radical scavengers, and thus decreasing the extent of oxidative damage [38]. Several factors related to dietary antioxidants such as poor solubility, inefficient permeability, instability, extensive first pass metabolism and rapid gastro-intestinal degradation, which have limited their extensive use; hence a therapeutic strategy may be formulated where antioxidant capacity of the cells may be used for long term effective treatment [39]. GC-MS analysis provides the idea about the chemical structure, molecular formula and idea about the functional group present in the compound [40].

\section{CONCLUSION}

Components of essential oil of peel and leaves of Citrus macroptera Montruz. Were identified. Oil yield were found to be $1.43 \%$ and 0.46 $\%$ in peel and leaves respectively. The oil yield \% denotes peel as better source of volatile oil than leaves. The same compounds has also been detected in both the essential oil but the relative percentage composition of the essential oil were different. Essential oil of peel as well as leaves exhibit antioxidant and antiinflammatory activity. From the calculated activity based on $\mathrm{IC}_{50}$ values, essential oil of peel showed more anti-oxidant and antiinflammatory activity than leaves oil.

\section{ACKNOWLEDGMENT}

We acknowledge Dr. Ajai Kumar, Incharge GC-MS Facility, Advanced Instrumentation Research Facility Jawaharlal Nehru University, New Delhi for Gas chromatography coupled with mass spectrophotometry. We extend our thanks to DBT, Govt. of India for financial support to carry out the study, and also to the Director, IBSD, Imphal for providing the laboratory facilities for carrying out the studies.

\section{AUTHORS CONTRIBUTION}

The study concept was designed by Dr. Ch. Brajakishore Singh, Data acquisition, data analysis and manuscript preparation was done by Kh. Nongalleima. Final approval and overall checking was done by Dr. T. Ajungla.

\section{CONFLICT OF INTERESTS}

\section{Declared none}

\section{REFERENCES}

1. Azad N, Rojanasakul Y, Vallyathan V. Inflammation and lung cancer: roles of reactive oxygen/nitrogen species. J Toxicol Environ Health Part B: Crit Rev 2008;11:1-15.

2. Heitzer T, Schlinzig $\mathrm{T}$, Krohn $\mathrm{K}$, Meinertz $\mathrm{T}$, Münzel $\mathrm{T}$. Endothelial dysfunction, oxidative stress, and risk of cardiovascular events in patients with coronary artery disease. Circ 2001;104:2673-8.

3. Madamanchi NR, Vendrov A, Runge MS. Oxidative stress and vascular disease. Rev Endocr-Relat Cancer 2005;25:29-38.

4. Gope PS, Dutta AK, Makhnoon S, Banik S, Siddiquee MA, Kabir Y. Effect of solvent and extraction time on the antioxidant properties of Citrus macroptera. Int J Drug Dev Res 2014;6:28-35.

5. Razali N, Mat-Junit S, Abdul-Muthalib AF, Subramaniam S, Abdul-Aziz A. Effects of various solvents on the extraction of antioxidant phenolics from the leaves, seeds, veins and skins of Tamapeelus indica L. Food Chem 2012;131:441-8.

6. Ferrero-Miliani L, Nielsen OH, Andersen PS, Girardin SE. Chronic inflammation: Importance of NOD2 and NALP3 in interleukin1beta generation. Clin Exp Immunol 2007;147:227-35.

7. Abbas $\mathrm{AB}$, Lichtman $\mathrm{AH}$. Innate immunity. In: Basic Immunology, Functions and Disorders of the Immune System. 3rd ed. Amsterdam, The Netherlands: Elsevier; 2009.

8. Dreyer DL, Huey PF. Coumarins of Citrus macroptera. Phytochem 1973;12:3011-3.

9. Rahmatullah M, Khatun MA, Morshed N, Neogi PK, Khan SUA. A randomized survey of medicinal plants used by folk medicinal healers of sylhet division, Bangladesh. Adv Nat Appl Sci 2010;4:52-62.

10. Grover JK, Yadav S, Vats V. Medicinal plants of India with antidiabetic potential. J Ethnopharmacol 2002;81:81-100.

11. Malik SK, Chaudhury R. The cryopreservation of embryonic axes of two wild and endangered citrus species. Plant Genetic Resources: Characterisation Utilization 2006;4:204-9.

12. Malik SK, Chaudhury R, Dhariwal OP, Kalia RK. Collection and characterization of Citrus Indica tanaka and C. macroptera montr. wild endangered species of northeastern India. Genet Resour Crop Evol 2006;53:85.

13. Safford WE. Contr. U. S. Nat Herb 1905;9:226.

14. Ozanne-Rivierre F. In: Le Nyelâyu de Balade (NouvelleCale'donie), Collection Langueset Cultures du Pacifique, Peeters, Paris; 1998. p. 275.

15. Bakkali F, Averbeck S, Averbeck D, Idaomar M. Biological effects of essential oils-a review. Food Chem Toxicol 2008;46:446-75.

16. De Sousa DP. Medicinal essential oils: chemical, pharmacological and therapeutic aspects. 1st ed. Nova Science Publishers: New York, NY, USA; 2012. p. 236.

17. Horowitz RM. The citrus flavonoids. In: Sinclair WB. Ed. The Orange. Its Biochemistry and Physiology. University of California, Division of Agricultural Science, Los Angeles, CA; 1961. p. 334-72.

18. Peterson JMS, Dwyer J, Dsc RD. Flavanoids: dietary occurence and biochemical activity. Nutr Res 1998;18:1995-2018.

19. Sa RCS, Andrade LN, de Sousa DP. A review on antiinflammatory activity of monoterpenes. Molecules 2013;18:1227-54.

20. Sakthivel G, Dey A, Nongalleima Kh, Chavali M, Rimal Isaac RS, Surjit N Singh, Deb L. In vitro and in vivo evaluation of polyhedral formulation against russell's viper and cobra venom and screening of bioactive components by docking studies. J Evidence-Based Complementary Altern Med 2013;2013:1-12. http://dx.doi.org/10.1155/2013/781216

21. Das B, Choudhury MD, Dey A, Talukdar AD, Nongalleima Kh, Deb L. Antioxidant and anti-inflammatory activity of aqueous and methanolic extracts of rhizome part of Drynaria quercifolia (1.). Int J Pharm Pharm Sci 2014;6:43-9.

22. Gangwar M, Gautam MK, Sharma AK, Tripathi YB, Goel RK, Nath G. Antioxidant capacity and radical scavenging effect of 
polyphenol rich Mallotus philippenensis fruit extract on human erythrocytes: an in vitro study. The Sci World J 2014. http://dx.doi.org/10.1155/2014/279451.

23. Bijina B, Chellappan S, Krishna JG, Basheer SM, Elyas KK, Bahkali AH, et al. Protease inhibitor from Moringa oleifera with potential for use as therapeutic drug and as seafood preservative. Saudi J Biol Sci 2011;18:273-81.

24. Gupta V, Chauhan Sh, Prakash A, Mathur A. Evaluation of in vitro and in vivo anti-inflammatory activities of Parthenium camphora. Recent Res Sci Technol 2013;5:33-9.

25. Sakat S, Juvekar AR, Gambhire MN. In vitro antioxidant and anti inflammatory activity of methanol extract of oxalis comiculata Linn. Int J Pharmacol Sci 2010;2:146-55.

26. Gaillard E, Muyard F, Bevalot F, Regnier A, Vaquette J. Rutaceae from new caledonia: chemical composition of stem bark of Citrus macroptera; 1995.

27. Rana VS, Blazquez MA. Compositions of the volatile oils of Citrus macropteraand C. maxima. Nat Prod Commun 2012;7:1371-2.

28. Waikedre J, Dugay A, Barrachina I, Herrenknecht C, Cabalion P, Fournet A. Chemical composition and antimicrobial activity of the essential oils from new caledonian Citrus macroptera and Citrus hystrix. Chem Biodiversity 2010;7:871-7.

29. Miah MN, Islam S, Hadiuzzaman S. Regeneration of plantlets through somatic embryogenesis from nucellus tissue of Citrus macroptera Mont. var. anammensis ('Sat Kara'). Plant Tissue Culture 2002;12:167-72.

30. Marzouk B, Ben Hadj Fredj M, Chraief I, Mastouri M, Boukef K, Marzouk Z. Chemical composition and antimicrobial activity of essential oils from Tunisian Mentha pulegium L. J Food Agric Environ 2008;6:78-82.

31. Bouchra $\mathrm{C}$, Achouri M, IdrissiHassani L, HmamouchiM. Chemical composition and antifungal activity of essential oils of seven moroccan labiatae against Botrytis cinerea Pers: Fr. J Ethnopharmacol 2003;89:165-9.

32. Pavela R. Insecticidal activity of some essential oils against larvae of Spodoptera littoralis. Fitoterapia 2005;76:691-6.

33. Larousse M. Encyclopédies des plantes médicinales larousse/VUEF; 2001. p. 234.

34. Lewis DA. Anti-inflammatory drugs from plants and marine sources. Basel: Bikhauser Verlag; 1989.

35. Cotran RS, Kumar V, Robbins SL. Pathologic basis of disease. Saunders WB company. Philadelphia, USA; 1994

36. Dharmasiri JR, Jayakody AC, Galhena G, Liyanage SSP, Ratnasooriya WD. Anti-inflammatory and analgesic activities of mature fresh leaves of Vitex negundo. J Ethnopharmacol 2003;87:199-206.

37. Park JH, Son KH, Kim SW, Chang HW, Bae K, Kang SS, et al. Antiinflammatory activity of Synurus deltoids. Phytother Res 2004;18:930-3.

38. George M, Britto SJ. Phytochemical, antioxidant and antibacterial studies on the leaf extracts of Curcuma amada Roxb. Int J Curr Pharm Res 2016;8:32-8.

39. Kale MA, Bindu SM, Khadkikar P. Role of antioxidants and nutrition in oxidative stress: a review. Int J Appl Pharm 2015;7:1-4.

40. Chintamani K, Dikshit M. Extraction, antioxidant potential and identification of secondary metabolites of whole fruits of Santalum album Linn by GCMS. Int J Curr Pharm Res 2015; 7:240-2.

\section{How to cite this article}

- $\quad$ Nongalleima Khumukcham, T Ajungla, Chingakham Brajakishore Singh GCMS based metabolic profiling of essential oil OF Citrus macroptera montruz. Leaves and peel, assessment of in vitro antioxidant and anti-inflammatory activity. Int J Pharm Pharm Sci 2017;9(9):107-114. 